Case Reports in
Gastroenterology
Case Rep Gastroenterol 2021;15:290-295

DOI: $10.1159 / 000511761$

Published online: March 4, 2021

(C) 2021 The Author(s)

Published by S. Karger AG, Basel

www.karger.com/crg

This article is licensed under the Creative Commons Attribution-NonCommercial 4.0 International License (CC BY-NC) (http://www.karger.com/Services/OpenAccessLicense).

Usage and distribution for commercial purposes requires written permission.

\title{
Enteroendocrine Dysfunction in Two Saudi Sisters
}

\author{
Amna Basheer M. Ahmed Badr M. Rasheed Alsaleem \\ Department of Pediatric Gastroenterology/Hepatology, Children's Hospital, King Fahad \\ Medical City, Riyadh, Kingdom of Saudi Arabia
}

\section{Keywords}

Proprotein convertase $1 / 3 \cdot$ Intractable diarrhea $\cdot$ Malabsorption $\cdot$ Congenital enteropathy

\begin{abstract}
Proprotein convertase (PC) deficiency is a rare autosomal recessive disorder caused by mutations in proprotein convertase subtilisin/kexin type 1 (PCSK1). It is characterized by severe malabsorptive early-onset diarrhea, obesity, and systemic endocrinopathies. Only few cases have been reported in the literature; we have add two female sisters with some difference in clinical progress. Herein, we describe two sisters with congenital osmotic diarrhea diagnosed with PC1/3 deficiency, causing malabsorptive diarrhea and enteroendocrine dysfunction, who presented with chronic enteropathy with hypernatremia but with different expressivity. PC1/3 deficiency presents with symptoms and signs that mimic glucose-galactose malabsorption. Because of the clinical paucity and heterogeneity of congenital enteropathies, whole-exome sequencing may be of great help towards early diagnosis and effective treatment.
\end{abstract}

(C) 2021 The Author(s)

Published by S. Karger AG, Basel

\section{Background}

Proprotein convertases (PCs) are a family of serine endoproteases responsible for the conversion of inactive propeptides into biologically active peptides [1]. Proprotein convertase subtilisin/kexin types 1 and 2 (PCSK1 and PCSK2) are two endoproteases mainly expressed

Amna Basheer M. Ahmed
Department of Pediatric Gastroenterology/Hepatology
Children's Hospital, King Fahad Medical City
PO 59046, Riyadh 11525 (Kingdom of Saudi Arabia)
amnabasheer13@yahoo.com




\section{Case Reports in Gastroenterology}

Case Rep Gastroenterol 2021;15:290-295 DOI: $10.1159 / 000511761$

c) 2021 The Author(s). Published by S. Karger AG, Basel www.karger.com/crg

Ahmed and Alsaleem: Enteroendocrine Dysfunction in Two Saudi Sisters

in the secretory pathway of neuroendocrine tissues where they are involved in tissue-specific processing of prohormones and neuropeptide precursors, such as pro-opiomelanocortin, prothyrotropin-releasing hormone, proinsulin, proglucagon, and progonadotropin-releasing hormone [2-6]. PC1/3 deficiency is an autosomal-recessive disorder caused by mutations in PCSK1. The clinical manifestation of PC1/3 deficiency is characterized by malabsorptive diarrhea, polyphagia with obesity, and certain endocrinopathies, including growth hormone deficiency, adrenal insufficiency, central diabetes insipidus, hypothyroidism, and primary hypogonadism [7]. Obesity is caused by mild homozygous as well as heterozygous mutations of PCSK1 [7-10].

The severe generalized malabsorptive diarrhea and malnutrition lead to increased mortality. Although systemic endocrinopathies evolve with age, the need for parenteral nutrition (PN) support decreases.Obesity, which is lessened by malabsorption, develops later in PC1/3 deficiency; however, enteroendocrine cell dysfunction is the principal underlying factor that leads to early clinical manifestation $[7,11,12]$.

Sequencing of target genes, such as NEUROG3, EPCAM, and MYO5B, can be done based on histology or nutrient absorption characteristics in genetic diarrheal disorders [13-16]. However, clinical data in these rare congenital diarrheal disorders may not be sufficient for sequencing known genes. Thus, whole-exome sequencing (WES) can discover known and novel mutations in known as well as unsuspected genes in a manner that efficiently directs clinical care $[11,17,18]$.

To date, 22 patients from 17 families with mutations involving PCSK1 have been described. Herein, we report two female siblings with PC1/3 deficiency manifested by congenital osmotic diarrhea with hypernatremia.

\section{Case Reports}

\section{Case 1}

The index case is a 1-month-old female infant (currently 6 years old) who presented with profuse watery diarrhea 10-15 times per day since day 13 of life. She required admission to the pediatric intensive care unit in the local hospital for management of severe dehydration and hypotensive shock which was associated with severe metabolic acidosis and hypernatremia. Serum sodium was $160 \mathrm{mmol} / \mathrm{L}$ (normal 135-145 mmol/L), serum chloride $124 \mathrm{mmol} / \mathrm{L}$ (normal 98-107 mmol/L), serum bicarbonate $5 \mathrm{mmol} / \mathrm{L}$ (normal 18-24 mmol/ L), serum potassium $2.8 \mathrm{mEq} / \mathrm{L}$ (normal 3.5-5.5 mEq/L), blood urea $3.4 \mathrm{mmol} / \mathrm{L}$ (normal 2.5$6.4 \mathrm{mmol} / \mathrm{L}$ ), and serum creatinine $53 \mu \mathrm{mol} / \mathrm{L}$ (normal $44-80 \mu \mathrm{mol} / \mathrm{L}$ ). After stabilization in the local hospital, the infant was referred to our institute because of persistent diarrhea of the same frequency and growth failure. She had been born by normal vaginal delivery at term, and the pregnancy had not been complicated by polyhydramnios. She ranked fourth in the family and the parents were second-degree cousins. Birth weight was $2.4 \mathrm{~kg}$ and length was $50 \mathrm{~cm}$. Family history revealed an older sister who had presented 6 years earlier with the same clinical features. Physical examination on admission showed a weight of $2.5 \mathrm{~kg}$ and a length of $49 \mathrm{~cm}$, both of which were below the third centile for age in the CDC growth chart. The abdomen was distended but without ascites or organomegaly. Serum electrolytes on admission revealed sodium $150 \mathrm{mmol} / \mathrm{L}$ (normal 135-145 mmol/L), potassium $3.6 \mathrm{mEq} / \mathrm{L}$ (normal 3.5-5.5 mEq/L), chloride $120 \mathrm{mmol} / \mathrm{L}$ (normal 98-107 mmol/L), magnesium $0.74 \mathrm{mmol} /$ $\mathrm{L}$ (normal 0.70-1.05 mmol/L), phosphate $0.7 \mathrm{mmol} / \mathrm{L}$ (normal 1.1-2.2 $\mathrm{mmol} / \mathrm{L}$ ), calcium

\section{Karger'=}




\section{Case Reports in Gastroenterology}

Case Rep Gastroenterol 2021;15:290-295 DOI: $10.1159 / 000511761$

c) 2021 The Author(s). Published by S. Karger AG, Basel www.karger.com/crg

Ahmed and Alsaleem: Enteroendocrine Dysfunction in Two Saudi Sisters

$2.6 \mathrm{mmol} / \mathrm{L}$ (normal $2.24-2.7 \mathrm{mmol} / \mathrm{L}$ ), serum creatinine $19 \mu \mathrm{mol} / \mathrm{L}$ (normal $44-80 \mu \mathrm{mol} / \mathrm{L}$ ), urea $11.9 \mathrm{mmol} / \mathrm{L}$ (normal 2.5-6.4 mmol/L), $\mathrm{HCO}_{3} 11.4 \mathrm{mmol} / \mathrm{L}$ (normal 118-24 mmol/L), and albumin $34 \mathrm{~g} / \mathrm{L}$ (normal 34-50 g/L). Other workup included tandem mass spectrometry and urine for organic acids, serum immunoglobulins, lymphocyte markers, blood culture, and abdominal ultrasonography; all came unremarkable. Fasting for $>24 \mathrm{~h}$ resulted in complete cessation of diarrhea. The measured fecal osmotic gap was very high (214.2 mosmol $/ \mathrm{kg}$, normal 50-100 mosmol/kg; measured fecal sodium $13 \mathrm{mmol} / \mathrm{L}$ and potassium $24.9 \mathrm{mEq} / \mathrm{L}$ ), indicating the osmotic nature of the diarrhea. Upper gastrointestinal endoscopy was done and the small intestinal biopsy was reported with villous atrophy with normal disaccharidase level. Genetic tests including EPCAM, MYO5B, and NEUROG came unremarkable. WES was conducted when it was available in our institute and revealed a homozygous mutation in PCSK (g.95735734_95735737del, NM_000439.4; c1350_1353del; p.Asp451fs), confirming the diagnosis of PC1/3 deficiency. The patient was managed by PN therapy and early introduction of oral feeds. PN was successfully discontinued at the age of 1 year following significant improvement of diarrhea and weight gain. However, PN was reintroduced following relapse of symptoms and growth cessation. Currently PN is on hold (by the family) with deterioration of growth (weight $14.3 \mathrm{~kg}$, height $102 \mathrm{~cm}$, both below the 3rd centile in the CDC chart, and a BMI of 13.75;10th centile). Additionally, she developed cortisol and growth hormone deficiencies and hypothyroidism (PCSK1 insufficiency-associated endocrine abnormalities) since the age of 3 .

\section{Case 2}

Six years earlier, an older sister (currently 12 years old) had presented to our center at the age of 6 months with the same problems of profuse watery diarrhea 10-15 times per day which developed at the same sister's age. She required multiple pediatric intensive care unit admissions in the referring hospital because of dehydration and electrolyte disturbances in the form of high serum sodium and chloride, hypokalemia, and metabolic acidosis. On admission to our institute both weight and height were below the $3 \mathrm{rd}$ centile (weight of $2.6 \mathrm{~kg}$ and length of $50 \mathrm{~cm}$ ). Systemic examination revealed severe wasting and abdominal distension, but there were no ascites, lower limb edema, or palpable organs. Serum electrolytes showed sodium $155 \mathrm{mmol} / \mathrm{L}$ (normal 135-145 mmol/L), potassium $2.5 \mathrm{mEq} / \mathrm{L}$ (normal 3.5-5.5 mEq/ L), chloride $125 \mathrm{mmol} / \mathrm{L}$ (normal 98-107 mmol/L), magnesium $0.7 \mathrm{mmol} / \mathrm{L}$ (normal 0.70$1.05 \mathrm{mmol} / \mathrm{L}$ ), phosphate $0.5 \mathrm{mmol} / \mathrm{L}$ (normal 1.1-2.2 mmol/L), calcium $2.1 \mathrm{mmol} / \mathrm{L}$ (normal 2.24-2.7 mmol/L), serum creatinine $55 \mu \mathrm{mol} / \mathrm{L}$ (normal $44-80 \mu \mathrm{mol} / \mathrm{L}$ ), urea $7 \mathrm{mmol} / \mathrm{L}$ (normal 2.5-6.4 mmol/L), $\mathrm{HCO}_{3} 10 \mathrm{mmol} / \mathrm{L}$ (normal 18-24 mmol/L), and albumin $30 \mathrm{~g} / \mathrm{L}$ (normal 34-50 g/L). Metabolic tests, immune deficiency tests, infectious tests, as well as abdominal ultrasonography were unremarkable. Fasting for $>24 \mathrm{~h}$ resulted in a complete resolution of diarrhea and fecal osmotic gap was significantly high $(170 \mathrm{mosmol} / \mathrm{kg}$; measured fecal sodium $45 \mathrm{mmol} / \mathrm{L}$ and potassium $15 \mathrm{mEq} / \mathrm{L}$ ), confirming the osmotic nature of the diarrhea. Based on the clinical features of osmotic diarrhea, hypernatremia, and metabolic acidosis, which suggests glucose galactose malabsorption, administration of Galactomin 19 milk formula did not result in improvement. Upper endoscopy and small intestinal biopsy revealed mild villous shortening. Moreover, mutation analysis of EPCAM and MYO5B as well as autoimmune enteropathy workup were unremarkable. At the age of 6 years and based on her sister's diagnosis, targeted mutation for PCSK1 was done and revealed the same sister's mutation. She did not require PN beyond the age of 11 months following gradual resolution of diarrhea and satisfactory weight gain. She has developed polyphagia and obesity (weight $53 \mathrm{~kg}$ [75th-90th

\section{Karger's'}




\section{Case Reports in Gastroenterology}

Case Rep Gastroenterol 2021;15:290-295 DOI: 10.1159/000511761

c) 2021 The Author(s). Published by S. Karger AG, Basel www.karger.com/crg

Ahmed and Alsaleem: Enteroendocrine Dysfunction in Two Saudi Sisters

centile], height $143 \mathrm{~cm}$ [10th-25th centile in the CDC chart] and a BMI of 25.98 [ $>97$ th centile]), but no endocrinological symptoms hitherto.

\section{Discussion}

This report describes the clinical pattern and genetic findings of two female siblings with PC1/3 deficiency, which was determined by WES. Generalized malabsorptive diarrhea, which is the early presenting feature, may be caused by impaired processing of prohormones secreted by enteroendocrine cells [7]. The early disease manifestations in our patients were severe diarrhea and failure to thrive. We found complete cessation of diarrhea upon fasting for $>24 \mathrm{~h}$, indicating its osmotic nature; however, other reports showed that fasting resulted in either a partial response or lack of improvement in diarrheal output $[7,19]$. This report shows that PC1/3 deficiency can occur in females [20], although they have been underrepresented in other studies $[7,21]$.

It is thought that PCSK1 is largely needed only during early infancy to support the necessary high-caloric intake, which explains the successful discontinuation of PN after the first 18 months of life $[7,11,12]$. However, one of our patient did not tolerate weaning off PN, which necessitated reintroduction of $\mathrm{PN}$ after reemergence of chronic diarrhea, metabolic acidosis, and cessation of weight gain, after other causes of chronic diarrhea had been extensively excluded.

An important aspect of our approach was using WES in the workup of these two patients to identify the underlying molecular etiology, because it was proven to be an efficient and powerful diagnostic tool in diagnosing enigmatic and rare disorders [11]. Previous reports showed that small intestinal histology has no role in diagnosing PC1/3 deficiency [7]; the same was true for our patients.

Early-onset obesity combined with severe polyphagia has been described in PC1/3 deficiency [22]. The older patient in this report is gaining weight progressively, reaching a BMI of $>97$ th centile; however, the younger patient's weight is fluctuating because of recurrence and persistence of her symptoms.

The youngest sister developed other endocrinological manifestations at an earlier age (3 years), namely hypothyroidism, adrenal insufficiency, and growth hormone deficiency for which the endocrinologist was involved in her management. However, the oldest 12-year-old sister has so far manifest neither of these associated endocrinopathies, though they might evolve later $[7,11,12]$. The difference in the clinical progress of the two sisters is possibly related to a difference in expressivity of the same mutation, with possible presence of a gene modifier.

In conclusion, $\mathrm{PC} 1 / 3$ deficiency should be considered in the differential diagnosis of osmotic and intractable neonatal diarrhea with hypernatremia and metabolic acidosis that mimic glucose-galactose malabsorption.

Some patients with PC1/3 deficiency may need long-term PN beyond infancy, which is dissimilar to what has been reported; therefore, a prospective multicenter study is warranted to further explore phenotypic-genotypic correlations.

Since PC1/3 deficiency is a rare disease, WES may be particularly helpful for the rapid and accurate diagnosis of congenital enteropathies because of the heterogeneity and paucity of clinical manifestations.

\section{Karger'"}


Case Reports in
Gastroenterology

\begin{tabular}{l|l}
\hline Case Rep Gastroenterol 2021;15:290-295 \\
\hline DOI: 10.1159/000511761 & $\begin{array}{l}\text { c 2021 The Author(s). Published by S. Karger AG, Basel } \\
\text { www.karger.com/crg }\end{array}$ \\
\hline
\end{tabular}

Ahmed and Alsaleem: Enteroendocrine Dysfunction in Two Saudi Sisters

\section{Statement of Ethics}

King Fahad Medical City Review Board (IRB) approved this case report study with IRB Log No. 17-165. The parents accepted publishing the case study, and as per the IRB policy, written consent is not required if there are no identifiers.

\section{Conflict of Interest Statement}

The authors have no conflicts of interest to declare.

\section{Funding Sources}

Not applicable.

\section{Author Contributions}

Both authors participated in the case report idea. A.B.M. Ahmed wrote the manuscript. Both authors participated in paper revision, reading, and final approval for publication.

\section{References}

1 Seidah NG. The proprotein convertases, 20 years later. Methods Mol Biol. 2011;768:23-57.

2 Ramos-Molina B, Martin MG, Lindberg I. PCSK1 variants and human obesity. Prog Mol Biol Transl Sci. 2016; 140:47-74.

3 Schaner P, Todd RB, Seidah NG, Nillni EA. Processing of prothyrotropin-releasing hormone by the family of prohormone convertases. J Biol Chem. 1997 Aug;272(32):19958-68.

4 Stijnen P, Ramos-Molina B, O’Rahilly S, Creemers JW. PCSK1 mutations and human endocrinopathies: from obesity to gastrointestinal disorders. Endocr Rev. 2016 Aug;37(4):347-71.

5 Farooqi IS, Volders K, Stanhope R, Heuschkel R, White A, Lank E, et al. Hyperphagia and early-onset obesity due to a novel homozygous missense mutation in prohormone convertase 1/3. J Clin Endocrinol Metab. 2007 Sep;92(9):3369-73.

6 Dong W, Seidel B, Marcinkiewicz M, Chrétien M, Seidah NG, Day R. Cellular localization of the prohormone convertases in the hypothalamic paraventricular and supraoptic nuclei: selective regulation of PC1 in corticotrophin-releasing hormone parvocellular neurons mediated by glucocorticoids. J Neurosci. 1997 Jan;17(2):563-75.

7 Martín MG, Lindberg I, Solorzano-Vargas RS, Wang J, Avitzur Y, Bandsma R, et al. Congenital proprotein convertase $1 / 3$ deficiency causes malabsorptive diarrhea and other endocrinopathies in a pediatric cohort. Gastroenterology. 2013 Jul;145(1):138-48.

8 Benzinou M, Creemers JW, Choquet H, Lobbens S, Dina C, Durand E, et al. Common nonsynonymous variants in PCSK1 confer risk of obesity. Nat Genet. 2008 Aug;40(8):943-5.

9 Philippe J, Stijnen P, Meyre D, De Graeve F, Thuillier D, Delplanque J, et al. A nonsense loss-of-function mutation in PCSK1 contributes to dominantly inherited human obesity. Int J Obes. 2015 Feb;39(2):295-302.

10 Creemers JW, Choquet H, Stijnen P, Vatin V, Pigeyre M, Beckers S, et al. Heterozygous mutations causing partial prohormone convertase 1 deficiency contribute to human obesity. Diabetes. 2012 Feb;61(2):383-90.

11 Yourshaw M, Solorzano-Vargas RS, Pickett LA, Lindberg I, Wang J, Cortina G, et al. Exome sequencing finds a novel PCSK1 mutation in a child with generalized malabsorptive diarrhea and diabetes insipidus. J Pediatr Gastroenterol Nutr. 2013 Dec;57(6):759-67.

12 Jackson RS, Creemers JW, Farooqi IS, Raffin-Sanson ML, Varro A, Dockray GJ, et al. Small-intestinal dysfunction accompanies the complex endocrinopathy of human proprotein convertase 1 deficiency. J Clin Invest. 2003 Nov;112(10):1550-60.

\section{Karger'=}




\section{Case Reports in Gastroenterology}

\begin{tabular}{l|l}
\hline Case Rep Gastroenterol 2021;15:290-295 \\
\hline DOI: 10.1159/000511761 & $\begin{array}{l}\text { @ 2021 The Author(s). Published by S. Karger AG, Basel } \\
\text { www.karger.com/crg }\end{array}$ \\
\hline
\end{tabular}

Ahmed and Alsaleem: Enteroendocrine Dysfunction in Two Saudi Sisters

13 Wang J, Cortina G, Wu SV, Tran R, Cho JH, Tsai MJ, et al. Mutant neurogenin-3 in congenital malabsorptive diarrhea. N Engl J Med. 2006 Jul;355(3):270-80.

14 Martín MG, Turk E, Lostao MP, Kerner C, Wright EM. Defects in Na+/glucose cotransporter (SGLT1) trafficking and function cause glucose-galactose malabsorption. Nat Genet. 1996 Feb;12(2):216-20.

15 Sivagnanam M, Mueller JL, Lee H, Chen Z, Nelson SF, Turner D, et al. Identification of EpCAM as the gene for congenital tufting enteropathy. Gastroenterology. 2008 Aug;135(2):429-37.

16 Müller T, Hess MW, Schiefermeier N, Pfaller K, Ebner HL, Heinz-Erian P, et al. MYO5B mutations cause microvillus inclusion disease and disrupt epithelial cell polarity. Nat Genet. 2008 Oct;40(10):1163-5.

17 Shendure J. Next-generation human genetics. Genome Biol. 2011 Sep;12(9):408.

18 Singleton AB. Exome sequencing: a transformative technology. Lancet Neurol. 2011 Oct;10(10):942-6.

19 Gönç EN, Özön A, Alikaşifoğlu A, Kandemir N. Long-term follow-up of a case with proprotein convertase 1/3 deficiency: transient diabetes mellitus with intervening diabetic ketoacidosis during growth hormone therapy. J Clin Res Pediatr Endocrinol. 2017 Sep;9(3):283-7.

20 Wilschanski M, Abbasi M, Blanco E, Lindberg I, Yourshaw M, Zangen D, et al. A novel familial mutation in the PCSK1 gene that alters the oxyanion hole residue of proprotein convertase $1 / 3$ and impairs its enzymatic activity. PLoS One. 2014 Oct;9(10):e108878.

21 Bandsma RH, Sokollik C, Chami R, Cutz E, Brubaker PL, Hamilton JK, et al. From diarrhea to obesity in prohormone convertase 1/3 deficiency: age-dependent clinical, pathologic, and enteroendocrine characteristics. J Clin Gastroenterol. 2013 Nov-Dec;47(10):834-43.

22 Härter B, Fuchs I, Müller T, Akbulut UE, Cakir M, Janecke AR. Early clinical diagnosis of PC1/3 deficiency in a patient with a novel homozygous PCSK1 splice-site mutation. J Pediatr Gastroenterol Nutr. 2016 Apr;62(4): 577-80. 